\title{
The Bitcoin - Democratic Money in a Neoliberal Economy
}

\begin{abstract}
This article examines the bitcoin, at present the most popular cryptocurrency. The bitcoin grew on the major pillars of the neoliberal market economy, such as liberalization, deregulation and privatization. But in the end, it turned out to be a cure for the dysfunctions of the financial system, which was based on neoliberal assumptions. The difficulty in capturing the character and status of the bitcoin still makes it elusive for the existing rules of law. Some governments observe the evolution of the bitcoin market with interest; others try to work against it. All of this makes the bitcoin an intriguing subject for research.

The aim of this article is to present the original assumptions of the bitcoin system; trace the reactions to the bitcoin's emergence in virtual reality, and next on the very real financial market; and analyze the reinterpretation of the idea that underlies the creation of the cryptocurrency. This article attempts to assess the bitcoin's potential of achieving a seemingly impregnable position on the global financial market.
\end{abstract}

Key words: cryptocurrency, block chain technology, p2p technology

\section{Introduction}

The bitcoin, which was invented more than eight years ago, is at present, the most popular cryptocurrency. Its collapse was prophesied many times due to its highly unstable exchange rate, and the continuous risk of cyberterrorist attacks that it is exposed to. Despite all this, the bitcoin has triumphed over all its adversaries. It gives a society the chance to restore control over a national currency through a decentralized settlement system, increasing access to communication technologies, and above all, by eliminating an intermediation on the financial markets. For these reasons, bitcoin has become known as democratic money (Wirdum; Bollier, and Conaty; Henisz, and Zelner).

Although the bitcoin will not replace traditional, international currencies anytime soon, a bitcoin technology - block chains - has the potential to revolutionize not only the banking sector, but also many others that create, use or control secured databases. The Wall Street Journal defined the bitcoin as the greatest financial innovation in 500 
years (Casey, and Vigna). In turn, the Bank of England compared the revolutionary nature of the bitcoin protocol, in terms of value transfer, to the internet protocol in terms of information transfer. The World Economic Forum projected that the bitcoin will come into common use within a decade, which could considerably influence the nature of contemporary economics (World Economic Forum Survey Report).

The present capitalization of the bitcoin market is over USD 154 billion, which gives the bitcoin first place among other cryptocurrencies (Table 1.).

Table 1. Cryptocurrency Market Capitalizations

\begin{tabular}{|c|c|c|c|c|c|c|c|}
\hline$\approx$ & Name & Wantert cas & Price & Volume (2en) & Cirevulating Supply & Change (24k) & Price Graph (7d) \\
\hline 1 & O Bitcoin & $\$ 154108304603$ & 59101,80 & $\$ 6345500000$ & $16 \$ 31462$ BTC & $684 \mathrm{~s}$ & \\
\hline 2 & - Ethereum & $\$ 57013247301$ & $\$ 579,96$ & $\$ 1867530000$ & $98323113 \mathrm{ETH}$ & $200 \%$ & \\
\hline 3 & -t Ripple & $\$ 27735031928$ & $\$ 0,700443$ & $\$ 649839000$ & 39094084840 XRP & $2.60 \%$ & \\
\hline 4 & wat Bitcoin Cash & 517953954533 & 51054,27 & 5467736000 & $17029750 \mathrm{BCH}$ & 8,025 & \\
\hline 5 & (c) Uteccoin & 59662503323 & $\$ 173,76$ & $\$ 809403000$ & SS T237si LTC & $8,47 \%$ & \\
\hline 6 & - Cardano & $\$ 5665957580$ & $\$ 0,218573$ & $\$ 253209000$ & 25927070538 ADA. & 17,325 & \\
\hline 7 & A NEO & $\$ 494446000$ & 576.07 & $\$ 216104000$ & ES 000 OCO NEO ". & $2.16 \%$ & \\
\hline
\end{tabular}

Source: https:/ / coinmarketcap.com/ (accessed on: 21 March 2018)

A total market capitalization of cryptocurrencies increased in March 2018 to about USD 352.8 billion and the bitcoin market shared about $44.3 \%$ of this value (Table 2.).

Table 2. Percentage of Total Market Capitalization

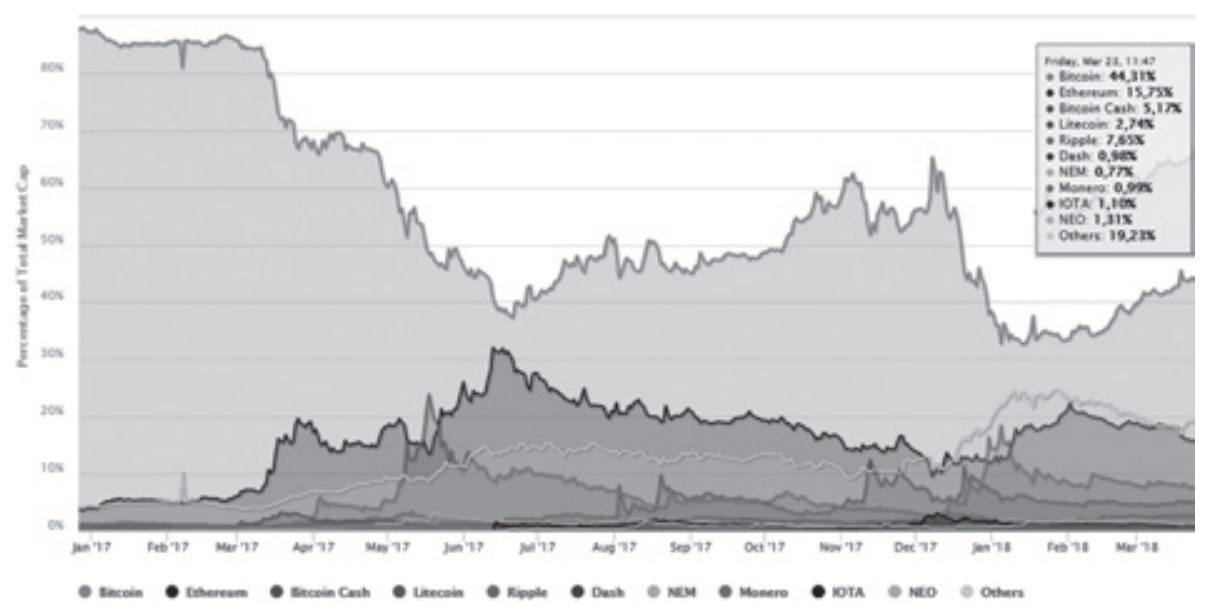

Source: https:/ / coinmarketcap.com/charts/ (accessed on: 23 March 2018) 
The bitcoin grew on the major pillars of the neoliberal market economy, such as liberalization, deregulation and privatization. But in the end, it turned out to be a cure for the dysfunctions of the financial system, resulting from the present structure of the system and limiting the democratic control over financial market. The difficulty in capturing the nature and status of the bitcoin still makes it elusive for the existing rules of law. Some governments observe the evolution of the bitcoin market with interest; others try to work against it. All of this makes the bitcoin an intriguing subject for research.

The aim of this article is to present the original assumptions of the bitcoin system; trace the reactions to bitcoin's emergence in virtual reality, and next on the very real financial market; and analyze the reinterpretation of the idea that underlies the creation of the cryptocurrency. This article attempts to assess the bitcoin's potential of achieving a seemingly impregnable position on the global financial market.

\section{The bitcoin - a novelty in the world of commerce and finance}

The bitcoin is a cryptocurrency, a digital currency that uses cryptography to create the currency's units, and make and secure the pseudo anonymous transactions. As opposed to the traditional system of electronic money, the verification and accounting of the transactions take place in a decentralized, virtual net and is based on so-called block chains ${ }^{1}$. Bitcoin technology dictates the disruptive nature ${ }^{2}$ of this innovation because block chains prevent the double spending of funds and make falsification of transactions practically impossible.

One creator and designer of the implementation methods is Satoshi Nakamoto. His identity has yet to be been confirmed. With regard to the quality of the bitcoin innovation, which combines simplicity with complex cryptography solutions, Nakamoto is considered to be a group of programmers. In 2008, Nakamoto presented the bitcoin, explaining its idea and mechanism in an article entitled "Bitcoin: A Peer-to-Peer Electronic Cash System" (Nakamoto). The project was registered on the SourceForge.net open-source platform, which engages a virtual society in the development and distribution of free software solutions. The first bitcoins were generated in January 2009 in a mining process. Anybody who has a computer, suitable software and internet access can be a bitcoin miner. Bitcoin mining is a process of verification and accounting of bitcoin transactions (Baron et al. 12-13). Every bitcoin holder has a wallet (pile) that contains a particular amount of currency. It operates in the bitcoin system as a code, as a wallet, and as a transaction carried out between two wallets. This is a complicated, mathematical formula that allows the verification of wallets and the generation of the transaction code. The miner generates the code and joins it to a code chain, and in doing so, earns bitcoins. The miner's salary is not

1 Each user has a pile (a bitcoin wallet) where the amount of the currency is held. A transaction conducted between two users gets a code and is plugged in a block. The blocks form a chain that is a virtual ledger of the global scope and free access.

2 "Disruptive innovation" is a grow-driven innovation that redefines the ways of problem solving. In its original meaning (disruption theory of C.M. Christensen and al.) corresponds to small firm targeting customers with an innovative but modest offering and posing a serious competitive challenge for the industry leaders. (Christensen, Raynor, and McDonald 44-45). 
paid by the transaction parties - the bitcoin system generates new money, automatically increasing the money supply. Nakamoto decided that the bitcoin system could provide a finite number of bitcoins, exactly 21 million. The last bitcoin will be mined between May and October 2140 depending on the increase of computing power and the effectiveness of the software.

In May 2010 the first bitcoin transaction was conducted. A programmer from Florida bought a pizza for 10,000 Bitcoins (BTC), which was then worth around USD 25. In 2009 and 2010, hackers ran pioneering experiments in the new technology field ${ }^{3}$. The society gathering around the bitcoin worked on ironing out the drawbacks of the system and improving its efficiency. At this time, the first mobile transaction and the short selling were conducted, and the first call option contract was sold. Since 2010, bitcoin users could run their transaction on the OTC market (over-thecounter). The market capitalization of bitcoin grew, achieving USD 1 million in 2010 and USD 1 billion in 2013, and the daily value of transactions conducted in bitcoin exceeded Western Union's transaction volume (Wile).

Gradually, the bitcoin idea attracted the attention of other environments. In October 2010, the independent, intergovernmental organization Financial Action Task Force on Money Laundering (FATF) warned against using cryptocurrency to finance terrorist activities in its report, "Money Laundering Using New Payment Methods" (FATF Report, 2010). A few months later the newly established online exchange, Silk Road, a black market platform, announced bitcoin as an official trading currency.

Despite partial damage of its reputation, the bitcoin market has constantly developed. From 2011 to 2013, start-ups in operating on the bitcoin market, for example, exchange markets for national currencies, companies providing and serving the bitcoin wallets, etc., flourished. However, investing in bitcoin was still risky; its rate fluctuated due to low liquidity and insufficient trust in the cryptocurrency as a store of value. Furthermore, relatively frequent cyberattacks on bitcoin wallets, fraud and leakages from exchanges occurred. Nevertheless, the turmoil surrounding the bitcoin did not deter investors from pumping their money into this insecure market. Venture capital funds invested more than USD 90 million in to the bitcoin company sector in 2013, and over USD 300 million in 2015. The scale of capital inflow to the sector exceeded the internet boom of 1995 (Mauldin).

The growing popularity of the bitcoin manifested through the increasing number of transactions resulted the blocks' size of $1 \mathrm{MB}$ becoming insufficient. The time of transaction increased which impeded small payments. The community agreed that the changes of the bitcoin protocol are necessary but there was no consensus as to what their character and scope should be. In August 2015, the lack of agreement divided the bitcoin community into two camps: an original Bitcoin Core and the alternative the Bitcoin XT. The new protocol expanded the bitcoin block to $8 \mathrm{MB}$ and enriched the cryptocurrency system with several new functions, i.e. a new solution for a double-spend transaction that allows users to be informed about the risk of making such transactions ${ }^{4}$ and amendments that facilitate multi-step financial applications, such as crowdfunding apps.

3 In a way that Jeremy Rifkin understands the term hacker, i.e. a smart, notably talented programmer.

4 The standard Bitcoin Core automatically rejects such transactions. 
The opponents of Bitcoin XT claim that the new protocol undermines user trust and denies Nakamoto's idea of cryptocurrency by centralizing the mining process. They claimed that the lack of agreement can lead to ceration of new bitcoin alternatives. These predictions came true. The new forks of bitcoin have emerged almost every month since the beginning of 2017. In 2017 Bitcoin Cash, Bitcoin Gold, Bitcoin Silver, Bitcoin Diamond, Lighting Bitcoin, Super Bitcoin and Private Bitcoin appeared, among others, on the cryptocurrency market. Some of them were immediately forgotten, the others stayed on the market for a little bit longer, like Bitcoin Cash, which was intended for making small transactions. Despite the mainstream media hailing that the forge was bitcoin's final failure, the market indicators regarding the exchange rate and market share of bitcoin do not support this judgement.

At present, the bitcoin market is arousing interest from the biggest Wall Street players. To fulfill these investors' needs, the New York Stock Exchange (NYSE) launched a new index: NYXT. It reflects the price trends of the bitcoin on the Coinbase exchange ${ }^{5}$, giving a global benchmark value to the bitcoin. The NYSE intends to build other indices on the basis of the cryptocurrency (Ferro) in relation to the development of the bitcoin derivatives markets in the US and the UK. Investors are able to trade Bitcoin futures on the Chicago Board Options Exchange and the Chicago Mercantile Exchange, and the Nasdaq is looking into bitcoin futures and preparing an offer that none of its competitors have managed so far (Kharpal).

The bitcoin is gradually strengthening its position on the international financial market. The market capitalization of bitcoin is still increasing and the major, world exchange markets constantly offer their investors new financial instruments based on the cryptocurrency value. Bitcoin promoters are intensifying their informational and educational efforts to accelerate the cryptocurrency's journey beyond the realms of hackers, speculators and libertarians. The bitcoin popularization process and development takes place simultaneously, accompanied by the increase of number of bitcoins in circulation ${ }^{6}$.

\section{Bitcoin - deregulation under control}

The launching of bitcoin itself did not have an ideological motive. In his article, Satoshi Nakamoto does not identify his project with any concept, ether libertarian or anarchist. His motives were purely pragmatic. It was about transaction cost reduction though the elimination of intermediation, and saving transaction time ${ }^{7}$.

Bitcoin grew in the neoliberal tradition of the market economy as a product of liberalization, deregulation and privatization. It draws its liberal nature from the achievements of the Austrian and monetarist schools of economy, which meant emphasizing the importance of the amount of money in circulation while removing the control over money supply form the competence of the central bank. The free-market

5 The NYSE assesses and analyzes the data from the other bitcoin exchanges to include them into the index in the future (Willms)

6 At present it is 15,189,300 BTC, and the market capitalization equals USD 5,698 million, In: https:/ / coinmarketcap.com/ (accessed on 9 February 2016).

7 The accounting time depends on the value of transaction and lasts between 4 minutes and an hour. 
feature of the bitcoin is primarily expressed in its free access to the cryptocurrency system, through public access to block chains and in the currency market mechanism itself. The cryptocurrency supply is fixed in advance and controlled by a mathematical formula ${ }^{8}$. Its changes are predictable and are extended in time. A mined bitcoin, as a miner's salary, becomes private money. Miners do not produce money, they are its transmitters. Bitcoin demand is freely stimulated on the market and its price is set the because of the fixed supply ${ }^{9}$. The bitcoin market, as well as the system, is decentralized and it is not under any institutionalized form of supervision.

The bitcoin, as a new technology, has never been the subject of deregulation. At the beginning, bitcoin circulation was an unregulated, no man's land; the market's architecture and organization were shaped purely by spontaneous adaptations. The cryptocurrency drew the attention of governments and supervisory institutions by the establishment and subsequent closure of the Silk Road exchange ${ }^{10}$. As the official black-market currency, the bitcoin was declared the money of terrorists and criminals. The cyberattacks on unsecure bitcoin wallets and bitcoin exchanges, as well as fraud, and especially the well-publicized collapse of the biggest bitcoin exchange market - MtGox, that followed, forced the governments to regulate the bitcoin market. A media frenzy around the cryptocurrency, and the chaotic trial of bringing it under existing financial laws and regulations, was catastrophic for the bitcoin exchange rate, undermining investors' trust and causing further decreases in value. Governmental agencies raced to define cryptocurrencies, giving them a variety of statuses, including goods, currency, financial instrument, etc. The regulatory chaos is still running, and it might turn out that cryptocurrencies will require a dedicated regulation framework. The list of major risks for stability and security, financial investors, still includes the bitcoin, although in the spirit of a liberal economy, the gains and losses resulting from running a business should concern the entrepreneur ${ }^{11}$. Despite market freedom and self-regulation being the main slogans on neoliberal economics' banners, reality seems to be different, especially in financial markets.

Governments share power over money with central banks with tremendous scope - deepening dangerous interdependences. The origin of central banking has an etatistic dimension. Giving the privilege of creating money to the central bank,

8 This solution approximates the bitcoin to the Milton Friedman's k\% rule that assumes continuously increase of money supply in relation to the value of the nominal income. Ultimately, Friedman dropped the idea of the mechanistic control of money supply appreciating the effectiveness of discretional instruments used by the Fed directed by Alan Greenspan (Friedman A8).

9 The model of fix supply and variable demand on the money market is one of the assumptions of the Austrian school of economics represented i.a. by Murray N. Rothbard (Rothbard 37-68)

10 The FBI investigation disclosed that the volume of the bitcoin transactions amount to BTC 600,000 (USD 1.2 billion) (Lee, and Tsukayama). The exchange closing did not resolve the problem of illegal trade. Less than a year after this incident Silk Road 2.0 was established, and a few hours later Silk Road 3.0. At present, the illegal trade was moved to the Dark Internet the Tor net.

11 On this occasion the completive conditions appear, e.g. full access to information. However the bitcoin market in its present nature and shape fulfills the informative functions as well as the traditional banking sector. 
the government automatically found a source for financing its activities. This guarantee very often led to excessive expenditure. In return, the government granted support to banks in times of crisis, which occurred very often in the face of banking panic. Despite the fact that modern financial systems, focused on effectiveness, and devoted to the free market idea, denounce these noxious practices, the same scenario is played out to this day, and has been consistently for over 300 years ${ }^{12}$.

Central banks primarily issue fiduciary money ${ }^{13}$, and the government gives it the privilege of being legal tender. The central bank fulfills many functions through which it influences the economic cycle. The basic functions include: controlling inflation; maintaining the stability of the financial market; and indirectly ${ }^{14}$, throughout the transmission mechanism of monetary policy, supporting economic growth and controlling unemployment levels ${ }^{15}$. The central bank controls the money supply within the context of regulating secondary money creation ${ }^{16}$, fulfilled by commercial banks. The strong interdependence between governments and banks distorts the relationship between the financial system and the real economy, enabling banks to achieve an advantage in prescribing the rules of the game ${ }^{17}$. The neoliberal fetishism of the invisible market hand, a belief in the mathematical precision of achieving equilibrium not backed by experience and a few decades of financial lobbyists hard work, paradoxically, led to the creation of a system of enormous asymmetry. Instead of entrepreneurship, deregulation unleashed the destructive power of capitalism ${ }^{18}$.

Neoliberal economics proclaims monetary policy superiority over a fiscal one, undermining the funds of the welfare state. Elżbieta Mączyńska and Piotr Pysz justify this status of monetary policy, in combination with a network; an information economy reshapes the position and functions of the modern state (Mączyńska, and Pysz 85-86). Proposals of Reaganomics and Thatcherism resulted in cuts of social expenditures, which together with a decrease in taxes, in the name of reinforcing the entrepreneurship, deteriorated the redistributive function of the state. The simultaneous drop in governmental investments and social benefits raised the specters of the debt trap. The decrease of budget revenues and households' transfers resulted in the rise of public and private debt, which changed future incomes. The banking system was a source of seemingly inexhaustible funds, to strengthen ties with the real economy subjects by means of credit. E. Mączyńska and P. Pysz highlight that, "nowadays we can almost not distinguish what is a state and what is market, and whether the state nationalized banks or banks privatized the state" (Mączyńska, and Pysz 86).

It seems that liberalization, in combination with self-regulation, gave birth to atavistic anarchism in the economy - but this is a misleading thesis. Predatory

12 The first central bank in history was established in 1694. More about this subject (Reinhart, and Rogoff; Aliber, and Kindleberger).

13 In the frame of the primary money creation the central bank can issue banknotes and coins, grant a loan to the commercial banks and manage foreign currency reserves.

14 In the American system the Fed is also responsible for the economic growth and full employment.

${ }_{15}$ In the American system the Fed fulfills those functions directly.

16 The secondary creation is conducted by the commercial banks, thus crediting companies and households.

17 More about this subject in: Bandelj, Wherry, and Zelizer.

18 More about this subject in: Stiglitz; Bogle; Sedláček. 
capitalism perverted the idea of free competition. Seemingly, the chaotic, self-regulating system at the beginning, characterized a considerable asymmetry of chances and opportunities. Firstly, it did not rise in a vacuum, but emerged as a result of a capitalistic system evolution. The former system had its leaders that influenced the assumptions of the new concept. One of the strongest players were the financiers that, soon after the Great Depression, made every effort to lift governmental control over its sector and open the door to foreign markets. In the second place, there were businessmen, owners of large corporations who, thanks to a decreases in taxes and, in the spirit of trickle-down theory ${ }^{19}$, had to take care of the households, by granting new jobs and fair salaries. Deregulation and liberalization in the banking sector led to a dangerous increase in the leverage scale, and hyper-competition on the debt market. As a result, a subprime debt market emerged and the process of deregulation continued. In turn, the liberalization of the labor market that was expressed in: flexible contracts, decreasing the minimum wage and undermining the trade unions, accelerates the increase of income inequality.

The market power of the financial conglomerates, blended with their political influence, led to a dangerous phenomenon: the financialization of the real economy. This is the process of the financial sector gaining relative autonomy and a superior position relative to sectors of the real economy (Ratajczak 282-283). It is made possible thanks to the syphoning of the financial surplus generated by real economy sectors. This surplus is invested perpetually in new, and increasingly complex financial instruments. This process takes on a hazardous nature ${ }^{20}$. The banking sector developed such an exceptional degree of creativity that controlling it posed a real challenge to the institutions charged with its financial supervision. Sometimes agencies do not cope with standards setting or even realize the type or scale of the risks ${ }^{21}$. A deepening complexity of the financial system, the level of its integrity and dynamic innovation, make governments more and more helpless in the face of the financial crisis. Governments reached a stalemate and had to reach into taxpayers' pockets to save the financial institutions, which are systemically important.

The financial crisis that appeared in 2008 exposed the limited responsibility taken, and uncritically profit-oriented approach of the banking sector. At the same time, governments remained firstly passive, and afterwards helpless, against pathologies that occurred in the financial system. Saving the huge financial conglomerates from bankruptcy abused the electorates' trust. These dependences partly explain why the bitcoin idea appealed especially to the anarchists and libertarians, who saw the gold of our age in the bitcoin, or a formula for a new, democratic type of money.

19 The IMF Analysts in their last report concerning the income inequality denied the verifiability of the trickle-down theory. According to that concept rich people cope with the income redistribution very well. Thus the government should decrease the taxes for wealthy people to encourage them to invest the surplus and create new working places. The rich are able to meet the social needs better than the bureaucratic state apparatus (Dabla-Norris et al.).

20 That is why the present capitalism is often called casino capitalism. Compare with Kowalik 68-88.

21 E.g. a securitization, that was invented in the 1970s was designed as an instrument of refinancing and hedging. Easing its original conditions increased the systemic risk on the international financial market and finally contributed to its collapse in 2008. 


\section{Bitcoin and economic democracy}

The financial crisis preceded a collapse of the international financial markets, and impaired societies' trust of the modern financial and economic system. It turned out that economic power, wielded until then by governments, was shifted to the private sector. A privatization of the economic power conducted in the spirit of neoliberal values was aimed at improving economic effectiveness and increasing social welfare. This strategy ended in failure. The marketization of government economic power delivered power to the hands of a few, weakening the democratic process. The substantial influence of markets, i.e. financial and non-financial corporations, on state policy and media, in some measure, disassociated societies from decisiveness in political and economic spheres. According to Nadia Johanisova and Stephan Wolf, a discussion about economic democracy ${ }^{22}$ should especially concern the regulation of the market mechanism, corporations' activities, support for social entrepreneurship, support of institutions of the common good, income and capital redistribution, and process of democratic money creation. The present mechanism of money creation and its influence on the quality of economic democracy are particularly crucial for bitcoin's existence.

In origin, money creation was a sovereign's domain. The emergence of central banking shifted that competence to the banking system. In fact, as opposed to commercial banks, the central bank is not a profit-oriented institution. Moreover, the commercial banks, through crediting and investment activity, in a certain sense designate the directions of economic growth. In the case of investments, one of the main criteria of project selection is the rate of return on invested capital, which is a measurable variable, in contrast to the unclear term of social welfare.

The money supply, and at the same time the ability to create money by the banking sector, became an imperative for economic growth. Expensive credit creates a restraint on investment and consumption, and means a decrease in the growth rate. A state's debt is vulnerable to the ratings assigned by the financial markets. A negative opinion results in the investors' withdrawal, and an increase in the cost of capital on the financial market that could badly influence the economy. In this case, states have to extend their effort to repay their debt with interest in the future. Governments are forced to increase their tax income and/or cut expenditure, companies have to sell more goods and/or cut costs, households increase their income and/or lower their standard of living. Increasing the GDP year by year means more goods on the market bought on credit. Thus, the market economy orbits toward the economy of surplus and waste concentrated capital, and power in the hands of a few ${ }^{23}$.

In view of these changes, the newborn bitcoin is perceived as democratic money ${ }^{24}$. It is worth looking at the bitcoin system in the prism of democracy values: freedom, sovereignty and self-government. The bitcoin holds freedom value through the decentralization of a transaction and settlement system that prevents an interference

22 The authors defined the term economic democracy as "a system of checks and balances on economic power and support for the right of citizens to actively participate in the economy regardless of social status, race, gender, etc." (Johanisova, and Wolf 564).

23 More about this subject: Kornai; Piketty.

${ }^{24}$ In the bitcoin community there is no agreement whether the bitcoin is democracy money or not. Compare (Wirdum). 
with government, financial institutions or any other party in the cryptocurrency's system (Wirdum). Bitcoin technology protects the property using cryptographic solutions that reduce the risk of sanctions or seizure, as well as counterfeiting and double-spending. The bitcoin status of medium of exchange is voluntary and depends only on the agreement of the transaction parties. Also, the existence of other currencies, including virtual ones, determines the freedom of choice, regarding bitcoin as a medium of exchange. Sovereignty is expressed in the lack of control over the bitcoin supply maintained by any central supervision institution. In this sense, bitcoin poses a challenge for the current central banking system that is not a subject of electorates' control, or the commercial banking sector, because of its private nature. On the other hand, the financing of bankrupting private companies is possible and needed. Investing in bitcoin, like any other currency, involves responsibility for the potential profits and losses that may occur as a result of changes in market and non-market indicators.

The openness of the bitcoin system and the potential of bitcoin application, especially block chains, are the main incentive for the intensified efforts of thousands of programmers worldwide. The bitcoin community runs a constant dialogue in on-line forums on bitcoin technology improvements and directions of development. In turn, open-source platforms fill up with innovative solutions for the identified failures and gaps in the system ${ }^{25}$. The decentralization of the bitcoin system and common, voluntary engagement in project development mean that the system gains a self-governmental nature.

The bitcoin system manifests the characteristics of a direct democracy. All uses have the same right to active participation in the system, regardless gender, sex, race, etc. The users do not control the currency supply, and neither does any other person. Thus, the bitcoin community does not need a system of checking balances belonging to an indirect democracy. Furthermore, bitcoin uses can decide which projects they financially support by taking part in crowdfunding actions or indirect money transfer. Ladislau Dowbor wrote that economic democracy expresses itself by embedding production processes, by providing sustainable access to elaborated results and by providing a guarantee of the right to choose (Dowbor 104). According to this definition the bitcoin seems to be highly democratic. Firstly, everyone who has access to the internet, and efficient hardware and software, has the right to be a miner. Secondly, the minimalizing of transaction costs through the elimination of the financial intermediation ${ }^{26}$ offers improved access to the profits resulting from bitcoin's use. Thirdly, each user has equal access to the information concerned with the amount of supply, price fluctuations, system failures, and directions of development. On that basis, investors can decide to operate in whichever currency is more profitable.

25 The list of chatrooms and the Internet sites that helps in communication in the bitcoin community among the bitcoin developers can be found on: e.g. https://bitcoin.org/en/development. The development projects are financed in frame of crowdfunding peer-to-peer platforms, e.g. Bitcoin Development Fund or Tip4commit.

26 At present, miners earn nothing or receive very low commisions for the accounting of transactions (fourth or fifth place after coma). Complete information about additional fees can be found on: https://en.bitcoin.it/wiki/Transaction_fees (accessed on 21 November 2016). 


\section{Bitcoin as a black market currency}

Governments noticed the appearance of bitcoin relatively late, at least officially. At the early stages, bitcoin was classified as a kind of danger because of the difficulty in controlling the bitcoin market. It was hard to identify bitcoin users, and there was no chance of blocking the wallets and withdrawing transactions. The Silk Road scandal only aggravated these anxieties. Bitcoin was categorized as a currency of black-marketeers, terrorists and money launderers. With time, bitcoin seems to have refuted these accusations, at least in the case of terrorism financing. In 2014, David S. Cohen, the undersecretary of the US Treasury Department said that bitcoin was not an alternative for traditional sources and means of terrorism financing or sanctions evasion (Dougherty, and Farrell). The latest Financial Action Task Force report (FAFT Report, 2015) from October 2015 indicates risks, but does not deliver hard evidence that bitcoin is used as a currency in such dealings. In turn, the Europol report on the Paris terrorist attacks of November 2015, does not confirm the hypothesis of a link between bitcoin and the Daesh's financing (Changes in modus operandi...). The bitcoin can be a means for criminal groups to evade capital controls or financial sanctions but at present the risk is irrelevant (2017 National Drug Threat Assessment). Bigger concern should be associated with the use of bitcoin in hacker attacks. Entities from North Korea, China and Eastern Europe turned to hacking tools such as ransomware to coerce victims to pay in cryptocurrency. According to the US government, the Bitcoin addresses associated with the attack contained about $\$ 150,000$ worth of the cryptocurrency by August 2017 (Cryptocurrencies and National Security). Ransomware attackers target businesses and local governments; as a result, companies are stockpiling bitcoins in the event of a hit (Goldman et al. 24). Despite these practices, experts claim that illicit use of virtual currencies, including bitcoin, indicates that terrorist use of the financial technology is not an imminent or systemic threat (Goldman et al. 28). Bitcoin's defenders, in fact, maintain that a major supporter of illegal activity is the present banking system, adducing many examples where international banks of the greatest repute, were engaged in illicit operations ${ }^{27}$.

Governments have cited another risk involving the spread of bitcoin's use: the reduction in efficiency of the monetary and fiscal policy operated by the government. The bitcoin could, then, undermine the monopoly of money creation and the control over the financial market shared by the government and the banking sector, thus becoming a safe haven for tax evaders.

In fact, the bitcoin could threaten national currencies' positions if it could influence the amount of money in circulation and the circulation rate. At present, bitcoin's influence on other currency supply is inconsequential because its volume is

${ }^{27}$ Global Research disclosed the facts concerning the incidents of breaking the anti-money-laundering rules by the biggest American banks, such as: Bank of America, JP Morgan Chase\&Co, Citigroup. Western Union was also involved in that case, (Murphy). The loudest money-laundering scandals includes the case of the Swiss branch of HSBC, where the clients were arms dealers and sanctioned entities, and the latest case of Deutsche Bank from November 2015. The German bank conducted financial operations for Soudanese, Iraqi, Burmese, Lebanese and Syrian entities imposed by financial sanctions, through its New York branch. The value of those operations amounted of almost USD 11 billion (Deutsche Bank zaptaci...), (Larson). 
insignificant. In the case of the circulation rate, intensified circulation encourages the holding of fiduciary money, thus causing the circulation rate of the national currency to increase (meaning its supply is higher). In response, a central bank should strengthen the monetary policy. An increase in a volume of the bitcoin's turnover, in combination with its value fluctuation could lead to significant uncertainty for the monetary policy. The central bank could fulfill its stability function by involving bitcoin in the monetary aggregates (Wen, and Arias). At present, bitcoin poses no risk for the monetary policy of any country.

The other issue for fiscal policy is the risk carried by the unregulated bitcoin market, especially in the face of the debt crisis that forced governments to look for additional income and/or to caulk the taxation system. In the situation where cryptocurrencies are exchanged for national currency, the justification for taxation is unquestionable. The state has a right to tax the interaction with the legal tender that it controls. The problem is that for tax reasons there is a need to identify a taxation subject. The term "cryptocurrency" has been defined differently. It has achieved the status of virtual currency, goods, service, sometimes property or financial instrument. The greatest challenge is to impose a value added tax (VAT) on the bitcoin. Assuming that bitcoin is a kind of a service, bitcoin's trade takes the form of a barter, thus should be subject to VAT. Firstly, it is difficult to determine the VAT rate because it depends on the place where the service is provided, the status of the buyer ${ }^{28}$, the place of their operation, and the address of the seller. Due to the pseudo-anonymous nature of bitcoin, the precise determination of these facts involves the cooperation of both of the transaction parties. Then, the parties in a bitcoin transaction cannot be treated equally. For example, if a bitcoin buyer is not a VAT payer, and the seller is, the former will avoid taxation. Such a transaction will not be preferable for a VAT payer because they could buy bitcoins on any exchange platform more cheaply (Nogacki, and Panas).

Previous experience in these areas has had the result that states resolved the issue of bitcoin's status independently. For example, in September 2015, the Commodity Futures Trading Commission (CFTC) defined the bitcoin as goods, and provided the bitcoin derivatives market with its supervision (Kawa).

In turn, in December 2015, the European Court of Justice (ECJ) concluded that bitcoin should be accepted as a legal tender, equal to other tenders that are used in transactions conducted by financial institutions (Haczyk). In light of these regulations, bitcoin should be discharged from obligations arising from VAT taxation. The ECJ judgment could be a hint for the architects of European legislation that suggests evolution because of the cryptocurrencies' occurrence.

States' reactions to the emergence and development of the bitcoin market range from leaving the bitcoin in the unregulated sphere to a ban of its use. Bitcoin transactions are forbidden in: Bangladesh, Bolivia, Ecuador, Island ${ }^{29}$, India ${ }^{30}$, Thailand ${ }^{31}$,

28 The status of the buyer means if the buyer is a VAT payer or not.

29 Iceland conducted an experiment with a national cryptocurrency - the Auroracoin that ended in failure. Despite this fact, Iceland's restriction did not involve bitcoin transactions but the export and import of the Iceland Corona.

30 The Indian government did not introduce the regulations forbidding the use of bitcoin, but it closed one of the biggest bitcoin exchanges - BTCXIndia - without giving a reason.

31 The bitcoin is legal because the present regulation has not constituted a way of proceeding with the cryptocurrencies. 
Russia $^{32}$, China and Vietnam ${ }^{33}$. Other countries, such as: Denmark, Belgium, Cyprus, Czech Republic, Japan, Estonia, Israel resisted regulation. Some of the states identified the scale of risk of bitcoin to security, and decided to impose money-laundering and terrorism-financing regulations (Canada, Hong Kong, Switzerland), or tax antievasion rules (e.g. the EU countries, Norway, Australia, Singapore, the US).

Usually, the bitcoin gains momentum in popularity more quickly in countries where internet access and use of new technology is common, and in countries of unstable financial systems where central banks take inflationary actions. Governments seek to gain control over the bitcoin market if they disperse the incomes deriving from seigniorage. The bitcoin is more easily implemented in countries that have experience in the regulation of market mechanisms, although if they have huge, unregulated markets (esp. shadow banking) the results cannot fulfill the expectation ${ }^{34}$.

Bitcoin market regulation can accelerate the building of trust of the cryptocurrency, and improve the transparency of its circulation and its predictability. The Polish Department of Economy declared its support for the bitcoin market regulation process at the European level. The Polish government perceives bitcoin as a chance to improve the competitiveness of Polish companies, and a way of easing the process of conducting intercontinental transactions, especially in the face of the negotiation of the latest trade and investment liberalization agreements: the Transatlantic Trade and Investment Partnership, and the Trans-Pacific Partnership ${ }^{35}$.

\section{The bitcoin and the banking sector}

The bitcoin can become a danger for the present form of the banking system, competing with the traditional approach to finance, not only by cost cutting, but also by proposing an entirely new business model. Central banks seem to be keeping a watchful eye on developments. The Federal Reserve has not taken steps to regulate the bitcoin market yet, despite the fact that it points out the risk of negative consequences resulting from cryptocurrencies' development in the medium- and longterm $^{36}$ (Record of Meeting, Federal Advisory Council and the Board of Governors).

To begin with, banks tend to show considerable anxiety towards the bitcoin market's development, and put up barriers to impede the activity of users, by blocking, for example, their accounts or preventing bitcoin exchanges held in banks. Banks have prepared information campaigns to discourage their clients from conducting

32 At present, the Russian Duma is working on the new act easing bitcoin's use. It is going to license the use of alternative money that is authorized in the Commonwealth of Independent States, the EU (Samburaj).

33 In both countries the financial institutions are forbidden to trade in bitcoin and the governments discourage the other entities to use the bitcoin because of its dubious nature. More on this subject in: https://www.cryptocoinsnews.com/top-10-countries-bitcoinbanned/ (accessed on 11 October 2016).

34 This argument can explain the dynamic development of the bitcoin market in China (Hendrickson et al. 14).

35 The Polish Department of Economy intends to promote the cryptocurrency.

36 On the next meeting in May 2015, the FAC did not mention virtual currencies and the risk it indicated concerned mainly the illegal activity of non-banking institution on the American financial market. 
bitcoin transactions. Additionally, they lobbied to classify the bitcoin as a virtual money/currency and to broaden the scope of regulation under which bitcoin should be controlled, i.e. anti-money-laundering and financing criminal activity regulation, financial market consumer protection, licensing of financial activity, supervision, etc. Bankers opted to exclude bitcoin technology (block chain technology) from the definition of the bitcoin (CSBS Model Regulatory Framework...) because they were going to adopt the technology to improve their competitiveness on the financial market. Bitcoin technology can be used as a closed ledger with secure access, thus chain technology does not threaten the present shape of the banking system, but can help to minimize costs.

The banking sector's interest in bitcoin technology is a strong indication of the innovative chains' potential. The Nasdaq OMX Group started a pilot program aimed at using bitcoin technology to transfer and settle securities. In turn, the New York Securities Exchange (NYSE), the United Services Automobile Association (USAA), the second largest Spanish bank, BBVA, and the Japanese telecommunications giant, NTT DoCoMo, jointly invested USD 75 million in the bitcoin wallet and the payment processor, Coinbase (Haczyk). 42 banks established a consortium under the auspices of the FinTech start-up, R3CEV, to develop the capabilities of bitcoin technology on the financial market ${ }^{37}$.

The banking sector reversed the risk associated with the cryptocurrency to its favor. Bitcoin used as a currency, fell by the wayside, and bitcoin technology (block chains) took over. This technology could revolutionize the present business model of banks, improve and decrease operational costs, and help in financial market stabilization (Kharpal). Despite all these advantages, when one danger is mitigated, another appears. Randall Koszner predicts that the future will bring not only the absorption of new FinTech innovation by the financial institution, but also the offering of the financial services by companies that are at present the leaders in acquiring, analyzing and processing information, e.g. Google and Amazon (Kroszner). These kinds of companies will be more effective in assessing a client's creditworthiness, and will be able to offer less expensive and more effective payment systems. They can more easily manage to break down entry barriers through the developed and commonly available communication technology, and cheap data processing.

\section{Summary}

Bitcoin's future seems to frighten those who have gotten used to the existing order. The bitcoin is jostling for a position in the consciousness and the wallets of investors, although it is perceived as a highly risky investment. Apart from the instability of exchange rates and the issue of securing the system, the problem with the bitcoin is its pseudo-anonymous nature that hampers the delineation of the bitcoin's market structure. It is unknown which entities hold the biggest bitcoin reserves, if they are

37 Among these banks were the leaders of the banking sector, i.e. Bank of America, BNY Mellon, Citi, Commerzbank, Deutsche Bank, HSBC, Mitsubishi UFJ Financial Group, Morgan Stanley, National Australia Bank, Royal Bank of Canada, SEB, Societe Generale, Barclays, BBVA, Commonwealth Bank of Australia, Credit Suisse, Goldman Sachs, JP Morgan, Royal Bank of Scotland, State Street and UBS (Higgins). 
private or public, and what their capability of market animation is. Wider access to such information could improve the predictability of bitcoin exchange rate fluctuations, and thus moderate bitcoin's speculative nature and stabilize the cryptocurrency's market. The fragmentation of bitcoin's ownership could improve market liquidity and unleash the additional powers of demand that shape prices of an unconditioned supply. On the other hand, bitcoin promoters rightly emphasize that at this stage of bitcoin's evolution, greed and speculation are the best accelerators for the development of the cryptocurrency market (Rizzo). Despite the growing interest of the medium and large players in bitcoin investment from Wall Street, the market is still not big and liquid enough ${ }^{38}$ to compete with international currencies. This may not remain the case forever.

The question is over governments' relationship to bitcoin. The government seems to be confident in the fact that the bitcoin user can be identified in the system, but this is not fully justified. Simultaneously with the technological progress that led to identifying the bitcoin user, new software confuses the trail in the block chains ${ }^{39}$. Despite the fact that the present legal status is residual and various, it seems to be perfectly possible that governments will seek to evolutionally tighten their control over the bitcoin market, for example, through the licensing process. The necessity of fulfilling the legal requirements and maintaining dependence on government decisions carries the risk of corruption and political pressure, e.g. to gain access to the databases of clients that settle in bitcoins. The potential of a virtual currency is inspiring for governments of many countries, such as: Sweden, Venezuela and Ecuador, that are considering introducing the state-sponsored cryptocurrencies on their financial markets.

The analysis of long-term trends brings even more uncertainty. At the moment of mining the last bitcoin, transaction costs will probably increase. Bitcoin users will pay additionally for the verification and accounting of their transactions. The bitcoin market could lose its competitiveness to national currencies that will commonly use the technology of block chains by then.

The decentralized bitcoin system, without the built-in function of control and stabilization, conducted by the financial supervision institutions, appears to be a selfdestructive mechanism. In the situation of a permanent decrease in bitcoin demand, inflation will occur easily, depriving the bitcoin of its value ${ }^{40}$. In turn, a completed extraction of bitcoins involves the risk of deflation. The increase in bitcoin demand of the fixed and finite supply could result in the increase of bitcoin value in relation to other currencies. At the same time, the prices of goods and services given for bitcoins could drop, causing deflation (Kervick). According to the Keynesian theory of

38 The emergence of bitcoin banks could certainly increase the liquidity on the bitcoin market but it will negate the idea lying behind the bitcoin system, i.e. the direct and decentralized nature of the cryptocurrency's system. Nevertheless, a bitcoin bank has already been established. It is the Bitcoin Crypto Bank that invests the deposits on behalf of its clients. See, https:/ / bitcoincryptobank.com/ (accessed on 6 January 2017).

${ }_{39}$ A bitcoin mixing practice can be the best example, (A Simple Guide to Safely...).

40 This is an expression of a healthy competition on the financial market. The flagging interest in a currency as a subject of investment leads to its sell-out and decrease of its value. The existence of the central bank assures that the national currency does not disappear from the market, at least not for long. 
economics, the price decrease and the expectation of following drops, will encourage consumers to restrain from purchases, which deepens the deflation process. According to adherents of the Austrian School of economics, deflation is a temporary state that could be remedial ${ }^{41}$. The issue is complicated by the split in the bitcoin community and uprising the bitcoin forks. There is no unambiguous answer to the question as to whether the forge is an announcement of the bitcoin's end or resolving the threat of deflation.

The dilemmas connected with the inflationary or deflationary nature of the bitcoin acquired a new dimension in the face of the eventual possible of the bitcoin deposit and credit banks, based on a fractional reserve system. The final bitcoin supply could exceed the assumed BTC 21 million, but then the bitcoin system will become like the traditional banking system, featuring a monopoly on money creation. The bitcoin's forks emerging with extraordinary frequency introduce additional uncertainty in this area.

Disruptive innovation that bitcoin causes, emerges relatively rarely, destroying sectors and inspiring the rise of others. Bitcoin changed the nature of, and the way of thinking about money as well as its verification and data transfer. At present, thanks to the popularization of bitcoin technology, and a number of public and private implementation projects, bitcoin has initiated the emergence of a new normality.

\section{References}

Aliber, Robert Z., and Kindleberger, Charles P. Manias, Panics, and Crashes. A History of Financial Crises. Seventh Edition. Palgrave: Macmillan 2015.

"A Simple Guide to Safely and Effectively Tumbling (Mixing) Bitcoins." Darknet Market, July 10, 2015. Web. 28 March 2018. https://darknetmarkets.org/a-simple-guide-tosafely-and-effectively-mixing-bitcoins/.

Money Talks: Explaining How Money Really Works, edited by Nina Bandelj, Frederick F. Wherry, and Viviana A. Zelizer. Princeton, NJ: Princeton University Press, 2017.

Baron, Jashua, et al. National Security Implications of Virtual Currency. Examining the Potential for Non-state Actor Deployment, Santa Monica: RAND Corporation, 2015.

"Bitcoin is Not Democratic." Medium. Web. 28 March 2018. https://medium.com/@beautyon_/bitcoin-is-not-democratic-81f87158250a\#.eoz5xe8nh.

Bollier, David, and Conaty, Patrick. "Democratic Money and Capital for the Commons: Strategies for Transforming Neoliberal Finance Through Commons-Based Alternatives." Heinrich Böll Foundation, 2015. Web. 27 March 2018. www.boell.de/sites/default/files/ democratic_money_capital_for_the_commons_report_january2016.pdf.

Casey, Michael J., and Vigna, Paul. "Bitcoin and the Digital-Currency Revolution." The Wall Street Journal, January 23, 2015. Web. 3 March 2018. http://www.wsj.com/articles/ the-revolutionary-power-of-digital-currency-1422035061.

Changes in modus operandi of Islamic State Terrorist Attacks. Review Held by Experts from Member States and Europol on 29 November and 1 December 2015, Hague, January 18, 2016. Web. 28 March 2018. http://www.wienerzeitung.at/_em_daten/_wzo/2016/01/25/160125_

41 The decrease in prices largely concerned the production factors that give a change to increase production (see: Hülsmann). Apart from this, in an open economy, that process could lead to the increase in demand on the goods and services counted in national currencies, and at the same time, to the increase demand on national currencies and the decrease bitcoin value. 
1356_europol_dokument_aenderungen_in_der_verfahrensweise_mit_is_terroranschlaegen_pdf_englisch.pdf.

Christensen, Clayton M., Raynor Michael, and McDonald Rory. "What Is Disruptive Innovation?". Harvard Business Review 93, 12, 2015: 44-53.

CSBS Model Regulatory Framework for State Regulation of Certain Virtual Currency Activities, September 15, 2015. Web. 28 March 2018. https://www.csbs.org/regulatory/ep/ Documents/CSBS-Model-Regulatory-Framework(September\%2015\%202015).pdf.

Dabla-Norris, Era et al. "Causes and Consequences of Income Inequality: A Global Perspective". IMF Staff Discussion Note, June 2015. Web. 28 March 2018. https://www.imf.org/ external/pubs/ft/sdn/2015/ sdn1513.pdf.

"Deep Shift Technology Tipping Points and Societal Impact." World Economic Forum Survey Report, September 2015. Web. 28 March 2018. http://www3.weforum.org/docs/WEF_ GAC15_Technological_Tipping_Points_report_2015.pdf.

„Deutsche Bank zapłaci $258 \mathrm{mln}$ dol. za pranie brudnych pieniędzy”. TV24BIS, November 5, 2015. Web. 28 March 2018. http://tvn24bis.pl/pieniadze,79/deutsche-bank-zaplaci-kareza-pranie-brudnych-pieniedzy,591964.html.

Dougherty, Carter, and Farrell, Greg. "Treasury's Cohen Sees No Widespread Criminal Bitcoin Use". Bloomberg, March 18, 2014. Web. 28 March 2018. http:/ / www.bloomberg.com/ news/articles /2014-03-18/treasury-s-cohen-says-regulation-helps-virtual-currencies.

Dowbor, Ladislaw. Demokracja ekonomiczna: Alternatywne rozwiązania w sferze zarządzania społecznego. Warszawa: Książka i Prasa, 2008. Web. 20 January 2016. http://dowbor. org/2008/05/demokracja-ekonomiczna.html/.

Ferro, Shane. "You Can Now Track Bitcoin on the New York Stock Exchange." Business Insider, May 19, 2015. Web. 28 March 2018. http://www.businessinsider.com/ the-nyse-bitcoin-index-2015-5.

Friedman, Milton. "The Fed's Thermostat." The Wall Street Journal. Eastern Edition. New York. 19 August 2003: A8.

Goldman, Zachary K. et al. „Terrorist Use Of Virtual Currencies”. Energy, Economics E Security, May 2017. Web. 27 March 2018. https://www.lawandsecurity.org/wp-content/ uploads/2017/05/CLSCNASReport-TerroristFinancing-Final.pdf.

Haczyk, Dariusz. „Kupno bitcoinów zwolnione z VAT - tak orzekł Europejski Trybunał Sprawiedliwości." Wirtualna Polska, December 14, 2015. Web. 28 March 2018. http:/ finanse.wp.pl/kat,1033767,title,Kupno-bitcoinow-zwolnione-z-VAT-tak-orzekl-Europejski-Trybunal-Sprawiedliwosci,wid,17926717, wiadomosc.html?ticaid=115d75.

Haczyk, Dariusz. „Wall Street stawia na Bitcoin. Zainwestowali w Coinbase.” Money.pl, January 23, 2015. Web. 28 March 2018. http://www.money.pl/gospodarka/wiadomosci/artykul/wall-street-stawia-na-bitcoin-zainwestowali,36,0,1698340.html.

Hendrickson, Joshua, et al. "The Political Economy Of Bitcoin". Economic Inquiry, November 2, 2015: 1-15, http://dx.doi.org/10.2139/ssrn.2531518.

Henisz, Witold J., and Zelner Bennet A., "The Hidden Risks in Emerging Markets". Harvard Business Review, April 2010. Web. 27 March 2018. https://hbr.org/2010/04/ the-hidden-risks-in-emerging-markets.

Higgins, Stan. "12 More Banks Join Blockchain Consortium R3." Coindesk, December 17, 2015. Web. 28 March 2018. http://www.coindesk.com/twelve-banks-blockchain-consortium-r3/.

Hülsmann, Jörg Guido. “Deflacja: największe mity.” Instytut Misesa, September 23, 2005. Web. 23 March 2018. http:/ / mises.pl/blog/2005/10/23/234/.

“Japan to Consider Regulating Cybercurrency Exchanges after Mt. Gox Debacle." Japan Times, December 17, 2015. Web. 23 March 2018. http:/ /www.japantimes.co.jp/news/2015/12/17/business/ japan-panel-eyes-registration-system-for-virtual-currency-exchanges/\#.VqDiNyrhDWL.

Johanisova, Nadia, and Wolf, Stephan. "Economic Democracy: A Path for the Future?". Futures 44, 2012: 562-570, https:/ / doi.org/10.1016/j.futures.2012.03.017. 
Kawa, Łukasz. "Bitcoin Is Officially a Commodity, According to U.S. Regulator." Bloomberg, September 17, 2015. Web. 27 March 2018. http://www.bloomberg.com/news/articles/ 2015-09-17/ bitcoin-is-officially-a-commodity-according-to-u-s-regulator.

Kervick D., “Bitcoin's Deflationary Weirdness.” New Economic Perspectives, April 24, 2013. Web. 1 April 2016. http:/ / neweconomicperspectives.org/2013/04/talking-bitcoin.html.

Kharpal, Arjun. "Why Bitcoin's Tech Could 'Change Everything' for Banks." CNBC, December 31, 2015. Web. 27 March 2018. http:/ / www.cnbc.com/2015/12/31/blockchain-whatthe-big-banks-say-about-the-tech.html.

Kornai, Janos. Dynamizm, rywalizacja i gospodarka nadmiaru. Dwa eseje o naturze kapitalizmu. Warszawa: Fundacja Gospodarki i Administracji Publicznej, 2014.

Kowalik, Tadeusz. „Kapitalizm kasyna.” Kryzys. Przewodnik Krytyki Politycznej, Warszawa: Wydawnictwo Krytyki Politycznej, 2009: 68-88.

Kroszner, Randall S. "The Future of Banks: Will Commercial Banks Remain Central to the Financial System? University of Chicago, Booth School of Business, and NBER." University of Chicago, March 2015. Web. 27 March 2018. https://www.frbatlanta.org/news/conferences/ 2015/0330-fmc/proceedings.aspx.

Larson, Eric. "HSBC Faces 'Much Work' on Money-Laundering, U.S. Says.” Bloomberg, April 1, 2014. Web. 27 March 2018. http://www.bloomberg.com/news/articles/2014-04-01/ hsbc-faces-much-work-in-money-laundering-accord-u-s-says-1-.

Handbook of Digital Currency: Bitcoin, Innovation, Financial Instruments, and Big Data, edited by David Lee Kuo Chuen. Academic Press, 2015.

Lee, Timothy, B., and Tsukayama, Hayley. "Bitcoin Industry Reeling as Authorities Shut Down Silk Road Online Marketplace". Washington Post, October 2, 2013. Web. 27 March 2018. https:// www.washingtonpost.com/business/economy/bitcoin-industry-reeling-asauthorities-shut-down-silk-road-online-marketplace/2013/10/02/961b105a-2ba1-11e397a3-ff2758228523_story.html.

Mączyńska, Elżbieta, and Pysz, Piotr. „Liberalizm, neoliberalizm i ordoliberalizm.” Ekonomia dla przyszłości, fundamentalne problemy teorii ekonomii i praktyki gospodarczej. IX Kongres Ekonomistów Polskich, edited by Elżbieta Mączyńska. Warszawa: PTE, 2014: 221-247.

Mauldin, John. "The 5 Phases of Bitcoin Adoption." Forbes, December 23, 2014. Web. 27 March 2018. http://www.forbes.com/sites/johnmauldin/2014/12/23/the-5-phases-ofbitcoin-adoption/\#2715e4857a0b79529a745354.

Money Laundering Using New Payment Methods. FATF Report, October 2010. Web. 27 March 2018. http://www.fatf-gafi.org/media/fatf/documents/reports/ML\%20using\%20New \%20Payment\%20Methods.pdf.

Murphy, Daniel. "Money Laundering and The Drug Trade: The Role of the Banks." Global Research, September 30, 2013. Web. 27 March 2018. http://www.globalresearch.ca/moneylaundering-and-the-drug-trade-the-role-of-the-banks/5334205 4.01.2016.

Nakamoto, Satoshi. Bitcoin: A Peer-to-Peer Electronic Cash System. Web. 27 March 2018. https:/ / bitcoin.org/bitcoin.pdf.

Nogacki, Robert, and Panas, Adriana. "Bitcoin a podatek VAT", Skarbiec. Kancelaria Prawna, 2014. Web. 27 March 2018. http://www.kancelaria-skarbiec.pl/publikacje/bitcoiny-podatek-vat.html.

“One Bank Research Agenda." Bank of England Discussion Paper, February 2015. Web. 23 March. http://www.bankofengland.co.uk/research/documents/onebank/discussion.pdf.

Pieters, Gina, and Vivanco, Sofia. "Financial Regulations and Price Inconsistencies across Bitcoin Markets." Information Economics E Policy 39, 2017: 1-14, https://doi.org/10.1016/j. infoecopol.2017.02.002.

Piketty, Thomas. Kapitat w XXI wieku. Warszawa: Wydawnictwo Krytyka Polityczna, 2015.

Reinhart Carmen M., and Rogoff, Kenneth S. This Time Is Different. Eight Centuries of Financial Folly. Princeton: Princeton University Press, 2011. 
Ratajczak, Marek. “Finansyzacja gospodarki”. Ekonomista, 3, 2012: 281-302.

Record of Meeting, Federal Advisory Council and Board of Governors, May 9, 2014. Web. 27 March 2018. http:// www.federalreserve.gov/aboutthefed/fac-20140513.pdf.

Rizzo, Pete. "Barry Silbert: Private Blockchains Will 'Capitulate' to Bitcoin." Coindesk, September 22, 2015. Web. 27 March 2018. http://www.coindesk.com/ barry-silbert-private-blockchains-will-capitulate-to-bitcoin/.

Rothbard, Murray. Tajniki bankowości. Warszawa: Fijor Publishing, 2007.

Samburaj, Das. "Russian Legislature to Review Updated Bitcoin-Ban Seeking Bill in February." CCN.LA, January 12, 2016. Web. 27 March 2018. https://www.cryptocoinsnews. com/russian-legislature-review-updated-bitcoin-ban-seeking-bill-february/.

Savelyev, Alexander. "Contract Law 2.0: 'Smart' Contracts as the Beginning of the End of Classic Contract Law." Information \& Communications Technology Law 26, 2, 2017: 116-134. https:/ / doi.org/10.1080/13600834.2017.1301036.

The Fintech 2.0 Paper: Rebooting Financial Services. June 2015. Web. 27 March 2018. http:/ / www. finextra.com/finextradownloads/newsdocs/The\%20Fintech $\% 202 \% 200 \% 20$ Paper.PDF.

Wen, Yi, and Arias, Maria A. "What does money velocity tell us about low inflation in the U.S.?". Federal Reserve Bank of St. Luise, September 1, 2014. Web. 27 March 2018. https://www.stlouisfed.org/On-The-Economy/2014/September/ What-Does-Money-Velocity-Tell-Us-about-Low-Inflation-in-the-US.

Willms, Jessie. "New York Stock Exchange Launches Bitcoin Pricing Index NYXBT." Bitcoin Magazine, May 19, 2015. Web. 27 March 2018. https://bitcoinmagazine.com/articles/ new-york-stock-exchange-launches-bitcoin-pricing-index-nyxbt-1432068688.

Wirdum, Arron van. "Why Bitcoin Really Does Represent the Democratization of Money." Bitcoin Magazine. Web. 27 March 2018. https://bitcoinmagazine.com/articles/ bitcoin-really-represent-democratization-money-1395137137. 